\title{
SISTEM INFORMASI PENGAJUAN CUTI PEGAWAI NEGERI SIPIL DAERAH KOTA SAMARINDA BERBASIS WEB
}

\author{
Ahmad Rofiq Hakim ${ }^{1)}$, Azahari ${ }^{2)}$, Robby Ari Cahyadi ${ }^{3)}$ \\ ${ }^{1,2}$ Sistem Informasi, Stmik Widya Cipta Dharma \\ ${ }^{3}$ Sistem Informasi, Stmik Widya Cipta Dharma \\ $1,2,3$ Jl. Prof. M. Yamin No. 25, Samarinda, 75123 \\ E-mail : rofiq_93@yahoo.com ${ }^{1)}$, informatikawicida@gmail.com ${ }^{2)}$, robbycahyadi@ymail.com³
}

\begin{abstract}
ABSTRAK
Aplikasi Sistem Informasi Pengajuan Cuti Pegawai Negeri Sipil Daerah Kota Samarinda Berbasis WEB merupakan aplikasi yang dibangun untuk proses pengajuan cuti yang berbasis web.

Penelitian ini dilakukan pada Badan Kepegawaian Daerah (BKD) Kota Samarinda dengan menggunakan metode penelitian yaitu metode pengumpulan data, studi lapangan, studi pustaka, analisis kebutuhan, desain sistem, dan implementasi sistem.Flow Of Document (FOD), Flowchart, Contex Diagram (CD), Data Flow Diagram (DFD), Hierarchy Input Proces Output (HIPO), Entity RelationShip Diagram (ERD), Site Map. Aplikasi Ini dibangun menggunakan software yaitu Bahasa Pemrograman PHP, HTML, DreamWeaver MX, database yang digunakan MySQL. Aplikasi yang dibangun beroperasi pada Sistem Operasi Windows.

Adapun Aplikasi Sistem Informasi Pengajuan Cuti Pegawai Negeri Sipil Daerah Kota Samarinda Berbasis WEB telah membantu pihak Badan Kepegawaian Daerah (BKD) dalam mendata dan menginformasikan pengajuan cuti pegawai secara cepat dan tepat, juga dapat memberikan informasi kepada pegawai untuk mengetahui proses cuti di setujui ataupun tidak di setujui.
\end{abstract}

Kata Kunci : Website, Sistem Informasi, Cuti Pegawai

\section{PENDAHULUAN}

Badan Kepegawaian Daerah kantor Walikota Samarinda adalah suatu badan yang menangani urusan kepegawaian pada lingkungan kantor Walikota Samarinda. Untuk itu Badan Kepegawaian Daerah pada Kantor Walikota Samarinda berkeinginan untuk memproses pengajuan cuti pegawai Negeri Sipil Daerah Kota Samarinda.

Untuk memenuhi kebutuhan proses cuti pegawai maka diperlukan proses pengolahan data pendataan cuti pegawai, hal ini akan sangat membantu dalam mengetahui segala informasi mengenai cuti pegawai yang ada pada Pemerintah Daerah Kota Samarinda.

Permasalahan yang terjadi pada Badan Kepegawaian kota Samarinda, diantaranya adalah ketidaktersediaan Sistem yang dapat digunakan untuk mengolah data-data Pengajuan Cuti Pegawai Negeri Sipil, dan data yang ada saat ini masih menggunakan pencatatan pada Microsoft Office Excel

Berdasarkan penelitian dan pengkajian yang penulis lakukan terhadap permasalahan yang ada, maka penulis mencoba merancang suatu sistem informasi yaitu Sistem Informasi Pengajuan Cuti Pegawai Negeri Sipil Daerah Kota Samarinda yang diharapkan dapat membantu dalam hal proses pengajuan cuti pegawai negeri yang ada pada Pemerintah Daerah Kota Samarinda.

\section{RUANG LINGKUP PENELITIAN}

Dalam penelitian ini permasalahan mencakup

1. Cakupan Masalah

Permasalahan yang terjadi pada Badan Kepegawaian kota Samarinda, diantaranya adalah ketidaktersediaan
Sistem yang dapat digunakan untuk mengolah datadata Pengajuan Cuti Pegawai Negeri Sipil, dan data yang ada saat ini masih menggunakan pencatatan pada Microsoft Office Excel

2. Batasan-batasan penelitian Mengingat luasnya ruang lingkup permasalahan yang ada, maka perlunya diberikan batasan masalah yang meliputi hal sebagai berikut :

\section{User}

Dapat melakukan aktifasi data yang telah di inputkan oleh administrator sesuai NIP dan password.

1) Fasilitas Login

2) Fasilitas Ganti Password pegawai

3) Fasilitas Profil Pegawai

4) Fasilitas Ganti Profil Pegawai

5) Fasilitas Permintaan Cuti Pegawai

6) Fasilitas Permintaan Cuti yang di setujui

7) Fasilitas Permintaan Cuti yang di ditolak

8) Fasilitas Tampilan status Permintaan Cuti Pegawai

9) Riwayat Permintaan Cuti yang disetujui

\section{Administrator}

Dapat melakukan penambahan, pengapusan, pengeditan data pegawai dan hak akses masuk ke data user atau pegawai 

1) Fasilitas Login
2) Fasilitas Tambah data pegawai
3) Fasilitas Tampilan Data Pegawai
4) Fasilitas Ganti Password pegawai
5) Fasilitas Permintaan Cuti yang di setujui
6) Fasilitas Permintaan Cuti yang di ditolak
7) Fasilitas Tampilan status Permintaan Cuti Pegawai

3. Rencana hasil yang didapatkan

Untuk menghasilkan Sistem Informasi Pengajuan Cuti Pegawai Negeri Sipil Daerah Kota Samarinda, yang diharapkan dapat menjadi salah satu alternatif dalam mengolah data pengajuan cuti pegawai Negeri dan masalah pencetakan laporan yang dihadapi.

\section{BAHAN DAN METODE}

\subsection{Penjelasan Bahan}

Sistem adalah kumpulan dari komponenkomponen yang dihubungkan dengan berbagai macam interaksi atau antara hubungan yang secara kolektif bereaksi terhadap rangsangan atau kebutuhan dan memenuhi suatu tujuan atau fungsi. Sistem merupakan suatu kerangka dari unsur-unsur elemen prosedur saling terkait (Jogiyanto, 2006).

Informasi dapat diibaratkan sebagai darah mengalir di dalam tubuh manusia, seperti halnya informasi didalam sebuah perusahaan sangat penting untuk mendukung kelangsungan bagi perusahaan. Akibat bila kurang mendapatkan informasi, dalam waktu tertentu perusahaan akan mengalami ketidakmampuan menggontrol sumber daya, sehingga dalam mengambil keputusan-keputusan strategis sangat terganggu, pada akhimya akan mengalami kekalahan dalam bersaing dengan lingkungan pesaingnya (Fatansah, 2006).

Sistem Informasi adalahSekumpulan prosedur organisasi pada saat dilaksanakan akan memberikan informasi bagi pengambil keputusan dan untuk mengendalikan organisasi (Fatansah, 2006).

Database merupakan kumpulan dari data saling berhubungan satu dengan lainnya. (Nugroho, 2004)

PHP singkatan dari Hypertext Preprocessor yang digunakan sebagai bahasa script server-side dalam pengembangan web yang disisipkan pada dokumen HTML. (Peranginangin, 2006).

MySQL (My Structure Query Language) atau yang bisa dibaca "mai-se-kuel" adalah sebuah program pembuat database yang bersifat open source, artinya siapa saja boleh menggunakannya dan tidak dicekal (Nugroho, 2004).

Dreamweaver $M X$ adalah suatu bentuk program editor web yang dibuat oleh macromedia. Dengan program ini, seorang programmer web dapat dengan mudah membuat dan mendesain web (Nugroho, 2004).

\subsection{Metode}

Metode pengembangan sistem yang digunakan dalam penelitian ini adalah menggunakan metode waterfall

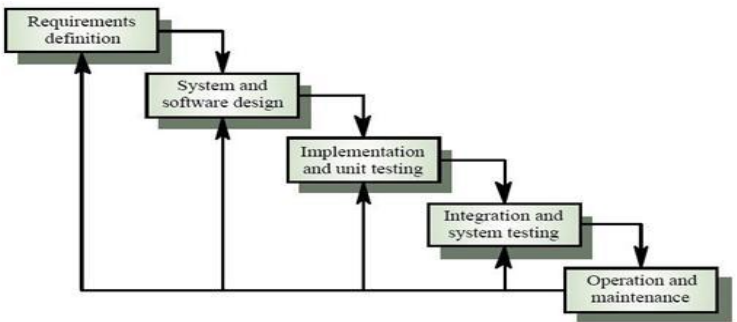

Gambar 1. Model Pengembangan Air Terjun

4. RANCANGAN SISTEM/APLIKASI

1. Flow Of Document (FOD) Yang Berjalan

Dimulai dari pegawai harus meminta form atau blangko perngajuan cuti ke BKD. Dan kemudian mengisinya untuk dimintakan persetujuan dan tanda tangan kepada Kepala Dinas dimana tempat pegawai tersebut bekerja. Setelah disetujui dan ditanda tangani oleh Kadisnya. Form pengajuan cuti yang telah ditanda tangani oleh Kadisnya oleh pengawai di serahkan kembali ke BKD pada bagian hukum, oleh bagian hukum di proses permohonan cuti tersebut dan menghasilkan Surat Cuti yang kemudian di mintakan tanda tangan kepada Kepala Dinas BKD. Setelah di tanda tangani Surat Cuti tersebut di berikan kembali kepada pegawai. Dan proses pengajuan cuti selesai.

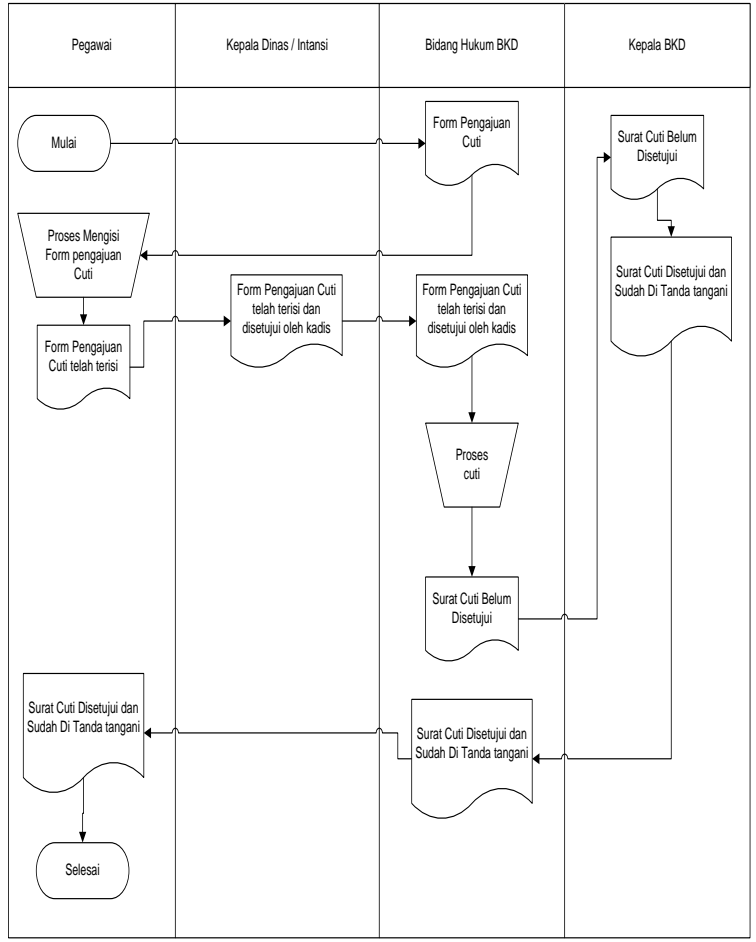

Gambar 2. FOD Yang Berjalan

\section{Flow Of Document (FOD) Yang Diusulkan}

Dimulai dari pegawai yang menginputkan data pegawai lalu di proses data pegawai dan di simpan di database yang bernama data pegawai lalu pegawai menginputkan permintaan cuti dan di proses 
permintaan cuti, setelah di proses data di simpan di database yang bernama permintaan cuti lalu data tersebut di proses permintaan cuti dan di simpan ke database permintaan cuti kemudian pegawai kemudian pegawai menyerahkan data tersebut ke bidang hukum BKD untuk di peroses setelah itu di simpan di dalam data base yang bernama database cuti kemudian pegawai mencetak surat cuti belum di setujui dan di tanda tangani, lalu di serahkan kembali ke bidang hukum BKD dan di serahkan kembali surat cuti belum di setujui dan di tanda tangani kepada Kepala BKD untuk di proses penandatanganan setelah di proses surat cuti belum di setujui dan di tanda tangani menjadi surat cuti sudah disetujui dan di tanda tangani di serahkan kembali ke bidang hukum BKD dan di arsipkan lalu di serahkan kepada pegawai tersebut.

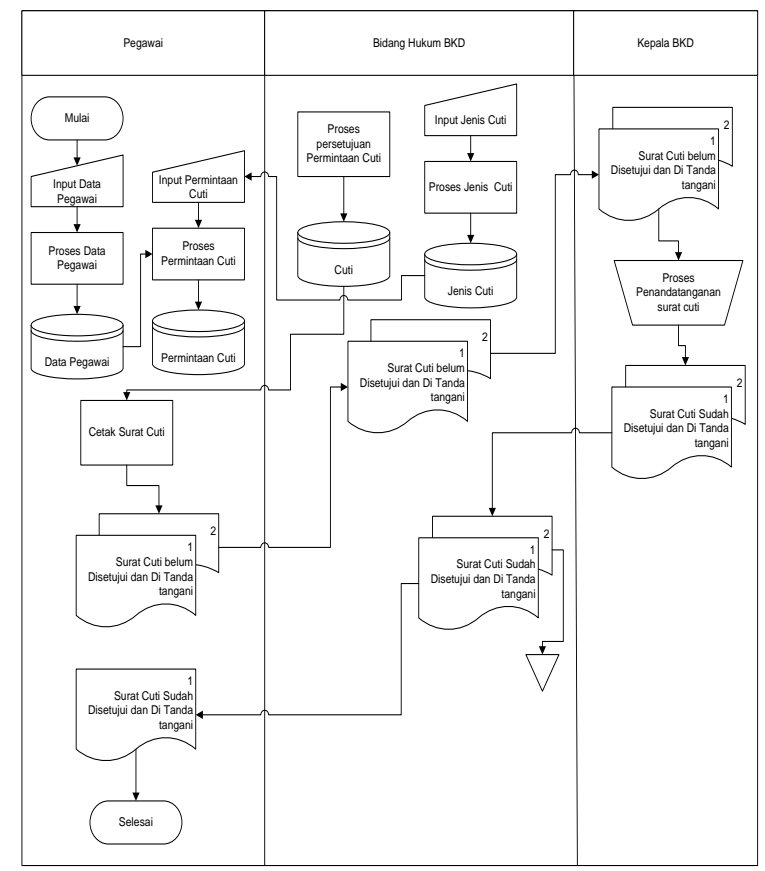

\section{Gambar 3. FOD Yang Diusulkan}

\section{Flowchart Proses pengajuan cuti Pegawai}

dimulai dengan user membuka alamat situs dan user akan ditampilakan halaman index atau halaman utama selanjutnya user akan diberikan pilihan apakah ingin melakukan permohonan cuti jika tidak maka user akan ditawarkan untuk melihat konten lainnya jika ya maka akan ditampilkan halaman index atau halaman awal jika tidak proses selesai, jika ya user akan melakukan permohonan cuti maka user harus melakukan Login kedalam system sebagai pegawai setelah itu user akan diminta untuk melakukan pengisian formulir permohonan cuti setelah itu user dapat melihat informasi kariawan yang telah diisi tadi jika semua data sudah diisi dengan benar maka user dapat logout dan keluar dari situs

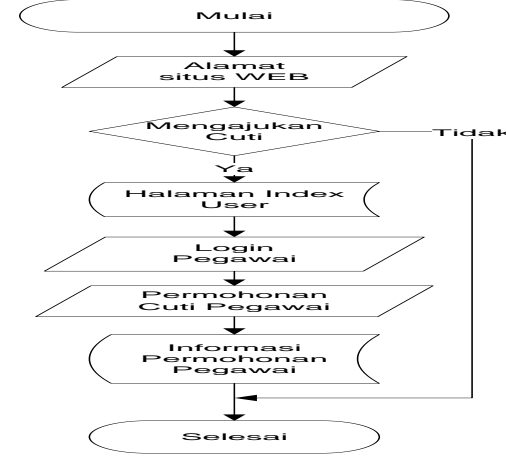

\section{Gambar 4 Flowchart pengajuan cuti}

\section{Flowchart Permintaan Cuti}

Flowchart permintaan cuti dimulai dengan menginputkan data pegawai kemudian pegawai juga menginputkan permintaan cuti. Selanjutnya pegawai menunggu permintaan cuti di setujui apa tidak oleh Pimpinan Badan Kepegawaian Daerah Kota Samarinda. Jika permintaan cutinya disetujui maka pegawai dapat mencetak surat cutinya. Dan jikalau permintaan cutinya tidak disetujui maka prosesnya akan selesai.

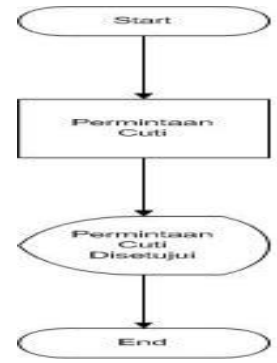

\section{Gambar 5 Flowchart Permintaan Cuti}

\section{Context Diagram}

Pegawai menginputkan data pegawai dan data permintaan cuti kemudian pegawai mendapatkan surat cuti yang sudah disetujui dan ditanda tangani oleh Kepala BKD. Bidang hukum menginputkan jenis cuti dan memperoses permintaan cuti yang di ajukan oleh pegawai dan bidang hukum menerima surat yang sudah disetujui dan ditanda tangani oleh Kepala BKD untuk di arsipkan.

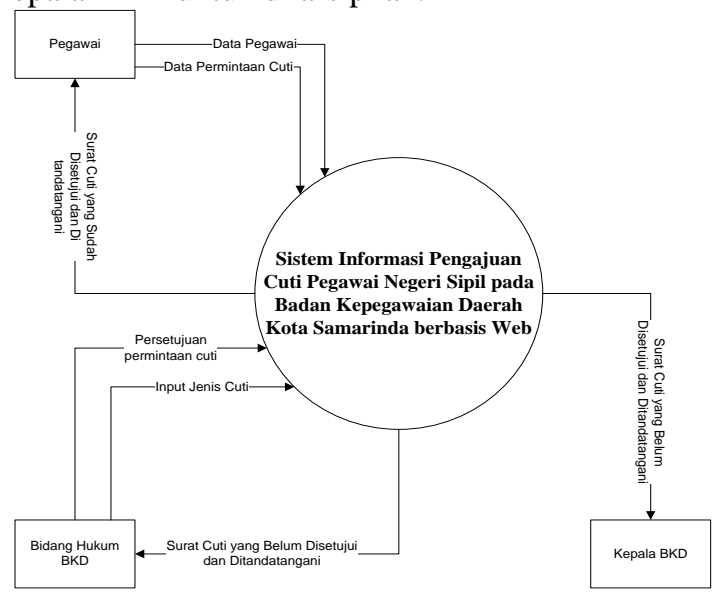

Gambar 6 Context diagram (CD) 


\section{Data Flow Diagram (DFD) Level 0}

Dari entitas pegawai menginput data pegawai dan disimpan kedalam database dengan nama entitas pegawai, setelah data tersebut di simpan, pegawai menginputkan data permintaan cuti, lalu data permintaan cuti di disimpan dengan nama tabel permintaan cuti. pada entitas bagian Bidang Hukum BKD memproses data persetujuan cuti yang menghasilkan permintaan cuti dan disimpan ke dalam database yang bernama tabel cuti, dan juga jenis cuti di input dan di proses yang menghasilkan jenis cuti dan di simpan dalam database dengan nama tabel jenis cuti, data cuti kemudian diproses dan di cetak yang menghasilkan surat cuti yang belum disetujui dan di tanda tangani kemudian di berikan ke entitas Kepala BKD untuk di tanda tangani lalu surat tersebut menghasilkan surat cuti yang sudah di setujui dan di tanda tangani kemudian di berikan kembali ke entitas bidang hukum BKD dan entitas pegawai tersebut.

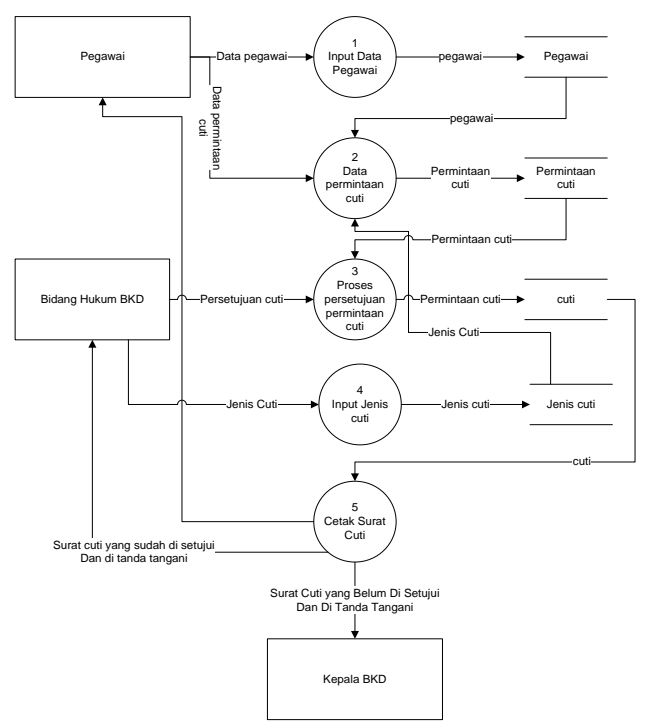

Gambar 7 Data Flow Diagram (DFD) Level 0

6.

\section{ata Flow Diagram (DFD) Level 1}

Dari tabel pegawai, tabel cuti dan tabel permintaan cuti, data diproses pada proses yang menghasilkan permintaan cuti dan di simpan kedalam data store cuti kemudian di proses kedalam surat cuti yang sudah disetujui dan di tanda tangani dan diberikan ke bagian hukum BKD untuk di sahkan dan di berikan pada pegawai tersebut.

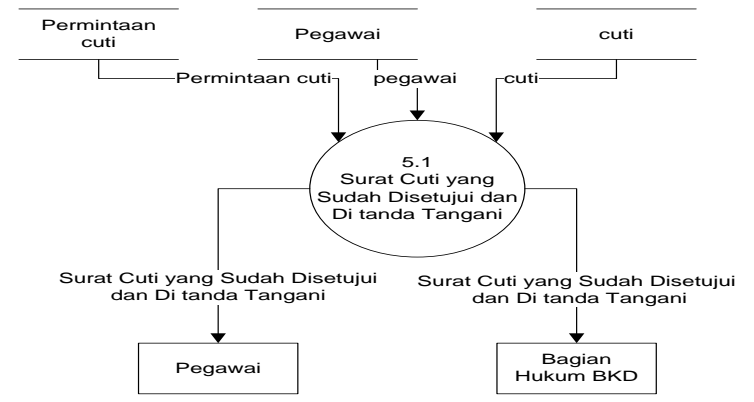

Gambar 8 Data Flow Diagram (DFD) Level 1

7. Hierarchy Input Proces Output (HIPO)

Dapat kita lihat bahwa Aplikasi Sistem Informasi Pengajuan Cuti Pegawai Negeri Sipil pada Badan Kepegawaian Daerah Kota samarinda berbasis web memiliki proses input data pegawai, input pengajuan cuti, input jenis cuti, proses persetujuan permintaan cuti, cetak surat cuti, yang menghasilkan surat cuti yang telah disetujui.

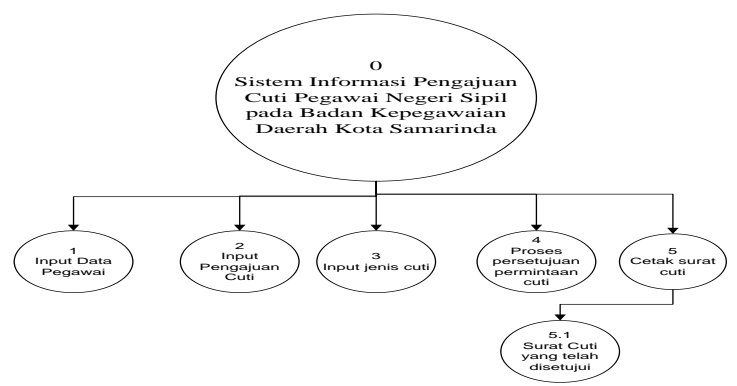

Gambar 9. HIPO Sistem

\section{IMPLEMENTASI}

Tampilan Halaman Login Cuti

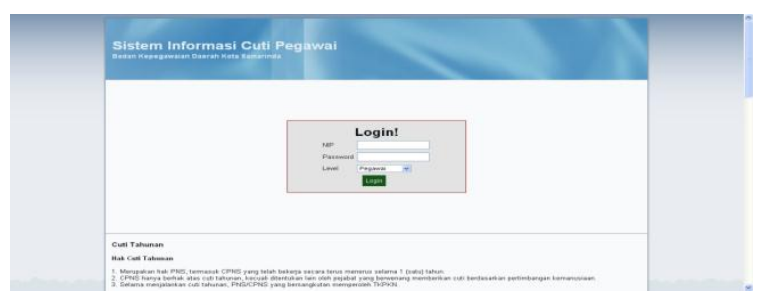

Gambar 10. Tampilan Halaman Login

berguna untuk masuk kehalaman administrator dan user untuk mengambil cuti, di tampilan user harus memasukan NIP pegawai dan memasukan password yang sudah di tentukan admin, di tampilan admin dapat melakukan pembuatan password dan nip yang sudah di tentukan dari data pegawai tersebut dan admin memiliki hak akses penuh untuk merubah data pegawai / user.

\section{Tampilan Depan Administrator}

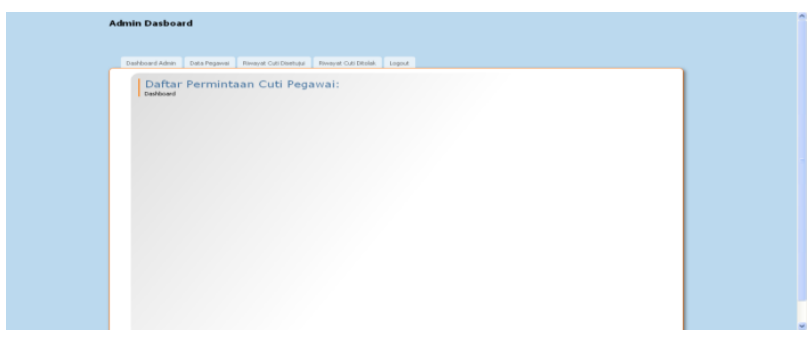

\section{Gambar 11. Tampilan Administrator}

Merupakan halaman daftar permintaan cuti pegawai yang belum melakukan permintaan cuti 


\section{Tampilan Data Pegawai}

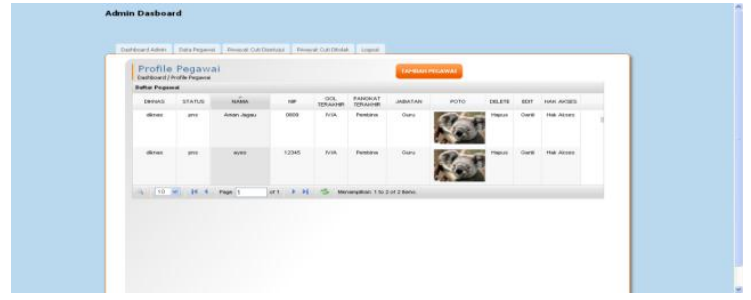

Gambar 12. Tampilan Data Pegawai

Halaman depan Profil Pegawai berguna untuk melihat riwayat cuti pegawai serta data pegawai tersebut.

\section{Tampilan Halaman Tambah Data Pegawai}

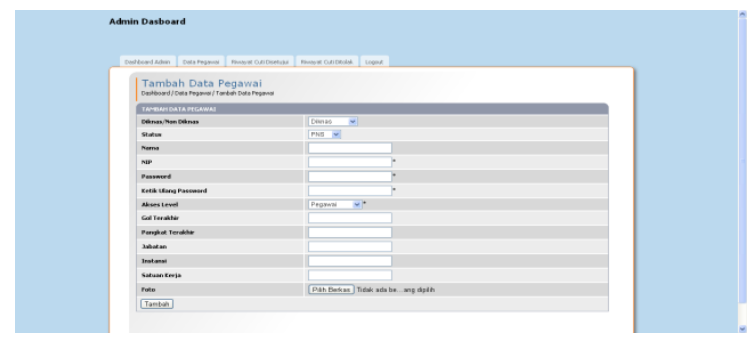

\section{Gambar 13. Tampilan Tambahan Data Pegawai}

berguna untuk menambah data tentang pegawai menginputkan nama, nip, gol serta data-data penting lainnya untuk di lengkapi.

\section{Tampilan Permintaan Cuti Disetujui}

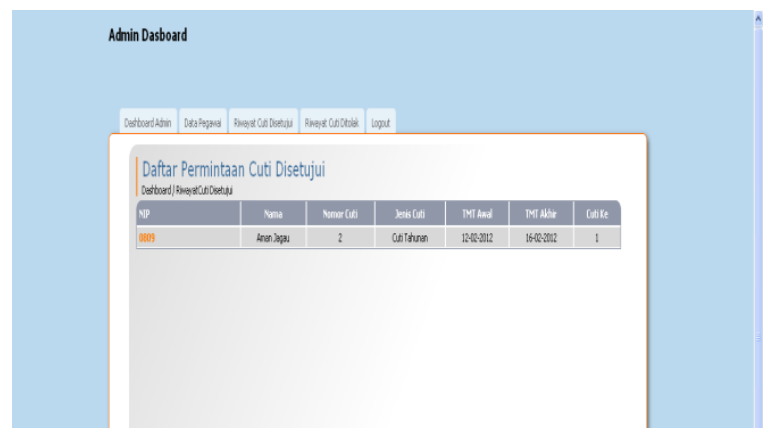

Gambar 14. Tampilan Perminataan Cuti Disetujui

Merupakan halaman yang menunjukan status permintaan cuti yang di setujui

\section{Tampilan Permintaan Cuti Ditolak}

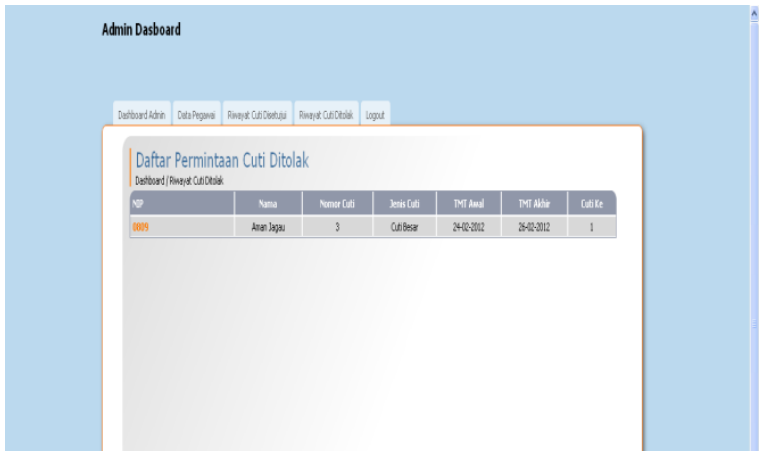

Gambar 15. Tampilan Permintaan Cuti Ditolak

Merupakan halaman yang menampilkan status permintaan cuti yang di tolak atau yang tidak di setujui

\section{Tampilan Halaman Status Permintaan Cuti Pegawai}

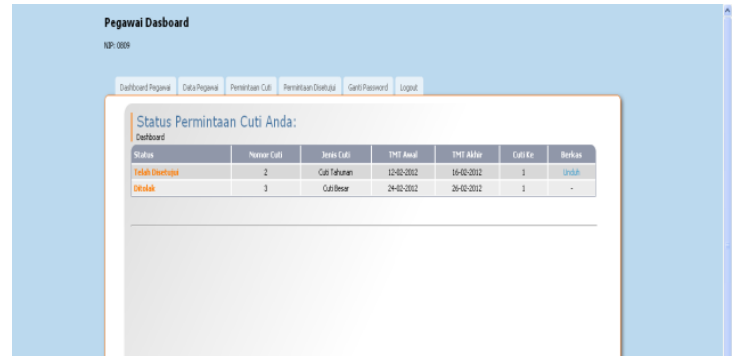

\section{Gambar 16. Tampilan Status Permintaan Cuti} Pegawai

Merupakan halaman berita yang berguna untuk menampilkan status user baik permintaan cuti yang di setujui atau tidak di setujui.

\section{Tampilan Profil Pegawai}

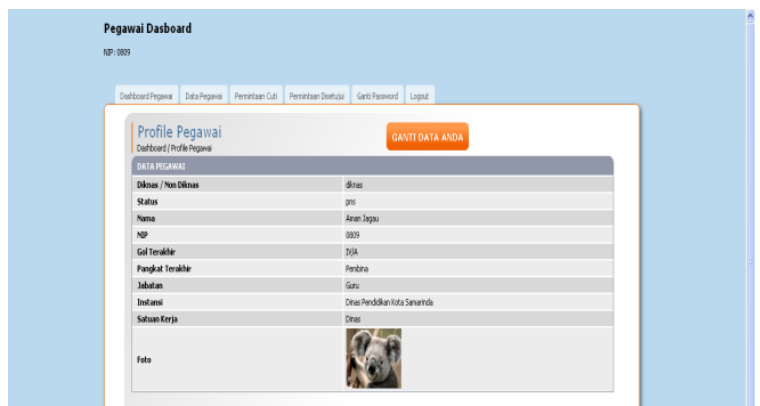

Gambar 17. Tampilan Profil Pegawai

Merupakan halaman data pegawai baik diknas atau non diknas, beserta status nama, nip, pangkat serta jabatan 


\section{Tampilan Ganti Profile Pegawai}

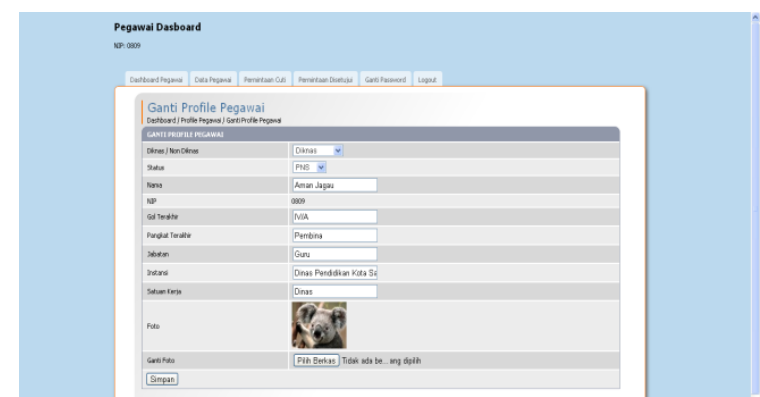

Gambar 18. Tampilan Ganti Profile Pegawai

Merupakan halaman data Pegawai yang berguna untuk menambah, mengedit data pegawai dan mengimputkan foto pegawai tersebut

\section{Tampilan Permintaan Cuti Pegawai}

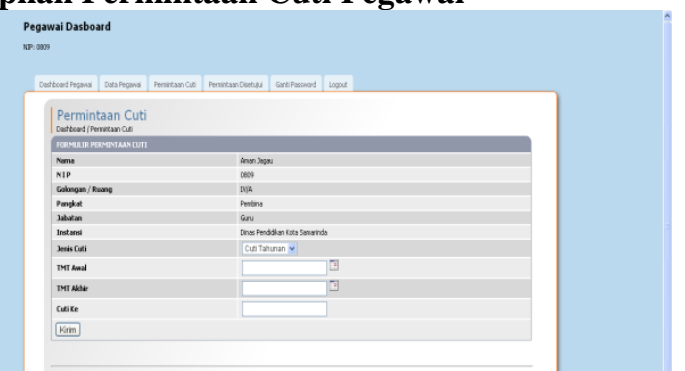

Gambar 19. Tampilan Permintaan Cuti Pegawai

Merupakan halaman user yang berguna untuk mengisi data permintaan jenis cuti pegawai yang akan di ambil

\section{Tampilan Riwayat Permintaan Cuti Yang} Disetujui

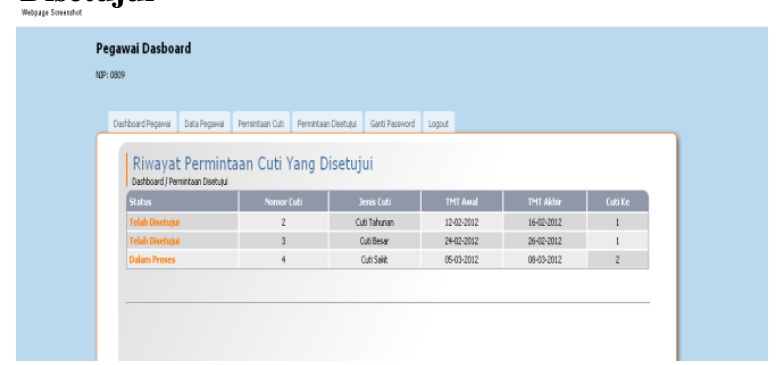

Gambar 20. Tampilan Riwayat Permintaan Cuti Yang Disetujui

Merupakan halaman yang menampilkan riwayat bagi pegawai untuk melihat permintaan cuti yang pernah di ambil.

\section{Tampilan Ganti Password User Pegawai}

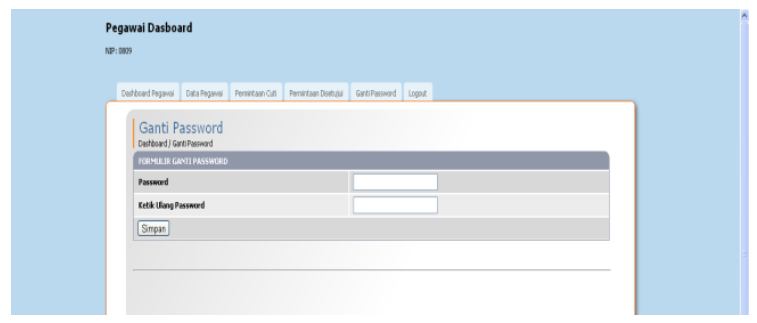

Gambar 21. Tampilan Ganti Password User Pegawai

Merupakan halaman yang berguna untuk merubah password pegawai tersebut yang sebelumnya sudah di beri dari administrator.

\section{KESIMPULAN}

Berdasarkan uraian dari masing-masing bab dan hasil pembahasan maka penulis dapat mengambil kesimpulan sebagai berikut:

1. Dengann adanya Sistem informasi Pengajuan Cuti yang berbasis web seperti ini akan mengefisiensikan waktu, pengajuan yang memakan waktu yang lama dan proses birokrasi administrasi yang rumit akan dengan mudah dan cepat dilakukan.

2. Dengan adanya system ini pegawai negeri sipil dapat mengajukan cuti dari mana saja dan kapan saja selain itu juga persetujuan cuti tidak harus menunggu kepala dinas datang dari luar kota karena persetujuan pengajuan cuti dapat dilakukan dimana saja oleh pegawai yang mengolah data ini sesuai dengan ketentuan.

\section{SARAN}

Dari pembahasan dan kesimpulan maka penulis memberikan saran sebagai berikut:

1. Website ini hanya mencakup pengelolaan cuti saja sehingga informasi tentang permasalahan lain seperti, pengelolaan data pegawai yang lebih rinci, dan informasi lainnya masih belum bisa ditampilkan jadi disarankan untuk kedepannya dari web ini dapat diperluas.

2. Informasi mengenai apakah permohonan cuti di setujui atau tidak masih dilakukan secara menual dengan menghubungi orang yang bersangkutan langsung.

3. Admin hanya bisa mengaprove atau menyetujui permohonan cuti dan tidak bisa melakukan rejected terhadap permohonan.

4. Aplikasi Sistem Informasi ini Jauh dari pada Kesempurnaan oleh karena itu penetili yang akan datang yang berminat untuk mengambangkan program ini agar dapat menambah berbagai macam jenis cuti dengan menyesuaian aturan yang berlaku pada masing-masing jenis cuti. Dan masih banyak memerlukan perbaikan di semua aspek dan interfacenya. 


\section{DAFTAR PUSTAKA}

Al Fatta, 2007, Analisis Perancangan Sistem Informasi, Yogyakarta : ANDI, edisi I

Jogiyanto HM, 2006, Analisis dan Desain Sistem Informasi, Andi Yogyakarta, Yogyakarta

Kristanto, 2000, Konsep dan Perancangan Database, PT Elex Media Komputindo, Kelompok Gramedia, Jakarta

Kusumo A.S, 2000, Microsoft Visual Basic 6.0, PT Elex Media Komputindo, Kelompok Gramedia, Jakarta, 1997, Metodelogi Pengembangan Sistem Informasi, PT. Elex Media Komputindo Kelompok Gramedia, Jakarta

KadirAbdul, 2006, Konsep \& Tuntunan Praktis Basis Data, Penerbit Andi Yogyakarta

Scoot, 2006, Prinsip-prinsip Sistem Informasi Manajemen, PT Raja Grafindo Persada

Pressman, Roger S, (2002), Rekayasa Prangkat Lunak: Pendekatan Praktisi (Buku I). Andi, Yogyakarta

Proboyekti. 2008. Software Process Model I.

Undang-undang Republik Indonesia Nomor 43 Tahun 1999 Tentang Perubahan atas Undang-undang Nomor 8 Tahun1974 Tentang pokok-pokok Kepegawaian 